\title{
Aplikasi Teknologi Tepat Guna untuk UMKM Pengolahan Sampah Organik sebagai Pakan Cacing
}

\section{Appropriate Technology Application for MSME Organic Waste Processing as Worm Feed}

\author{
${ }^{1}$ Aviv Yuniar Rahman, ${ }^{2}$ Feddy Wanditya Setiawan, ${ }^{3}$ April Lia Hananto \\ ${ }^{1}$ Program Studi Teknik Informatika, Fakultas Teknik, Universitas Widyagama Malang \\ 2 Program Studi Teknik Otomotif, Politeknik Hasnur Barito Kuala \\ ${ }^{3}$ Program Studi Sistem Informasi, Fakultas Teknik dan Ilmu Komputer, Universitas Buana \\ Perjuangan Karawang
}

Korespondensi: A.Y.Rahman, aviv@widyagama.ac.id

Naskah Diterima: 15 Agustus 2019. Disetujui: 14 Februari 2020. Disetujui Publikasi: 8 Maret 2020

\begin{abstract}
Waste is a problem that has not been resolved, therefore to reduce the adverse effects caused by waste, it is necessary to innovate waste management in order to have economic value. With this innovation in managing waste, the community can reduce the level of waste accumulation and reduce air pollution, especially for processing organic waste. CV. Rumah Alama Jaya (RAJ) Organics is a partner in this program because it produces worm feed using raw materials for organic waste. However, there are obstacles in the field of production that is a tool for making feed ingredients in worms that are still done in the traditional way and require a long time. The solution offered is to make an organic waste blender machine that can chop organic waste such as leaves and twigs to be used as worm feed. The methods used in making this waste treatment machine are location survey, group discussion, literature study, tool making, tool experimentation, and results evaluation. The results of the organic waste blender produce small particles of waste so it is faster to be processed to the next stage. With the help of this organic waste processing machine, the waste that has been chopped, fermented, and treated with this machine is capable of wasting the waste in 2 days. So, the production process becomes efficient because the process of eating worms is not too long and the process of accumulating waste is minimal.
\end{abstract}

Keywords: Blender machine, organic waste processing, worm feed.

Abstrak. Sampah menjadi masalah yang belum terselesaikan hingga saat ini. Oleh karena itu untuk mengurangi dampak buruk yang diakibatkan oleh sampah, maka diperlukan inovasi pengolahan sampah agar mempunyai nilai ekonomi. Dengan adanya inovasi mengelola sampah ini masyarakat dapat mengurangi tingkat penumpukan sampah dan mengurangi polusi udara, khususnya untuk mengolah sampah organik. CV. Rumah Alam Jaya (RAJ) Organik menjadi mitra dalam program ini karena memproduksi pakan cacing menggunakan bahan baku sampah organik. Namun, terdapat kendala pada bidang produksi yaitu alat cara pembuatan bahan pakan pada cacing yang masih dilakukan dengan cara tradisional dan membutuhkan waktu lama. Solusi yang ditawarkan yaitu membuat mesin blender sampah organik yang dapat mencacah sampah organik seperti daun dan ranting untuk dimanfaatkan sebagai pakan cacing. Metode yang dilaksanakan dalam pembuatan mesin pengolahan sampah ini yaitu survey lokasi, diskusi kelompok, studi literatur, pembuatan alat, percobaan alat, dan evaluasi hasil. Blender sampah organik mampu menghasilkan partikel-partikel kecil sampah sehingga lebih cepat diolah ketahap selanjutnya. Dengan bantuan mesin pengolahan sampah organik ini sampah yang sudah di cacah, difermentasi, dan diolah dengan mesin ini cacing mampu menghabiskan limbah tersebut dalam 2 hari sehingga proses produksi menjadi efisien karena proses makan cacing tidak terlalu lama dan proses penumpukan sampah semakin minimal.

Kata Kunci: Mesin blender, pengolahan limbah organik, pakan cacing. 


\section{Pendahuluan}

Sampah menjadi masalah yang belum terselesaikan hingga saat ini. Pengelolaannya masih terbatas sehingga sampah seringkali menjadi masalah serius (Mahyudin, 2017). Kurangnya penanganan sampah akan mengganggu pencemaran lingkungan dan mengakibatkan perkembangan penyakit di lingkungan tersebut (Alfan, 2017). Untuk itu perlu pemahaman tentang pengelolaan sampah yaitu berupa pengurangan dan penanganan sampah kepada masyarakat (Suryani, 2014). Persoalan penanganan tersebut perlu upaya pemberdayaan kepada masyarakat sekitar (Arnawa \& Pandawani, 2019). Dalam mengembangkan potensi yang dimiliki masyarakat perlu diarahkan untuk pemberdayaan (Meilani \& Kartika, 2019) serta dalam partisipasinya akan mewujudkan kemandirian dan kesadaran diri masyarakat (Munawir, dkk., 2019). Pengelolaan sampah yang masih rendah ini menjadi masalah yang serius, seiring dengan tingkat pertumbuhan penduduk yang semakin banyak jumlahnya dari pada sampah yang dihasilkan (Alfiandri, dkk., 2018). Menganalisis permasalahan yang dihadapi dalam pengelolaan sampah di Indonesia, di antaranya kurangnya tempat pembuangan yang tidak memadai, serta kurangnya usaha masyarakat dalam kesadaran dan pengelolaan sampah yang dilakukan (Humaedi, dkk., 2018).

Peningkatan jumlah penduduk juga dapat meningkatkan jumlah timbulan sampah (Masrida, 2017). Selain itu peningkatan sampah yang tidak seimbang dengan sampah yang dikelola di TPA sampah (Mahyudin, 2017). Kota Malang sebagai contohnya, kota yang sering menghadapi persoalan sampah. Kota Malang mempunyai luas wilayah $110.060 \mathrm{~km}^{2}$ dengan jumlah penduduk sekitar 831.123 (Pratiwi, dkk., 2018). Kota ini bisa dikategorikan kota besar yang keberadaannya pun tidak jauh dengan permasalahan sampah. Sekitar 69\% timbunan sampah yang merupakan hasil dari sampah rumah tangga sedangkan $31 \%$ sisanya berasal dari sampah pasar, fasilitas pertokoan, fasilias industri, sampah jalan, sampah pertamanan, dan sampah dari fasilitas kesehatan (Sudiro, dkk., 2018). Jika jumlah sampah melebihi kapasitas yang ditampung akan menimbulkan rendahnya tingkat stabilitas dan batas toleransi dari suatu perekonomian (Antin, dkk., 2018). Selain itu pengaruh yang dihasilkan juga akan merusak lingkungan yang ada di sekitar. Masalah sampah saat ini juga akan berpengaruh pada masa yang akan mendatang. Dampak dari sampah jika terus menerus dibiarkan akan menjadi suatu pola hidup masyarakat yang tidak teratur terhadap lingkungan dan kesehatan pribadi (Susmarkanto, 2002). Oleh karena itu perlu pengolahan sampah untuk membantu pengurangan sampah yang berlebihan (Martana, dkk., 2018). Dengan pengelolaan sampah tersebut akan bermanfaat bagi lingkungan, perekonomian, pendidikan, pemberdayaan, sosial dan diri sendiri. Akan tetapi, masyarakat belum memahami cara pengolahan sampah (Rukminasari dkk., 2016). Salah satunya yaitu pengolahan sampah organik agar mempunyai nilai ekonomi (Lando dkk., 2019).

Kelurahan Sukun merupakan salah satu contoh pengelolaan sampah yang masih menggunakan sistem lama, yaitu mengumpulkan sampah di angkut dan di buang di tempat pembuangan akhir. Sistem pengelolaan sampah seperti ini masih bertumpu terhadap waktu (Salendu \& Hadi, 2018). Oleh karena itu sampah yang disebabkan oleh masyarakat, sudah harus menjadi tanggung jawab bersama dalam pengelolaannya serta seluruh masyarakat harus bisa menjaga dan mengatur kebersihan lingkungan (Aprilia, 2016). Dalam pengelolaan ini, sampah juga bisa di jadikan sebagai sarana untuk pakan ternak, terutama pakan cacing. Dalam pakan ternak cacing di daerah tersebut saat ini menggunakan blotong. Blotong ini adalah hasil sampingan dari proses klarifikasi nira tebu di industri pabrik gula (Angelo, dkk., 2019). Blotong termasuk dalam kategori limbah organik yang memiliki potensi untuk dapat dimanfaatkan lebih lanjut seperti pakan cacing (Astuti, 2019). 
Sampai saat ini blotong masih menjadi salah satu alternatif para peternak cacing untuk sarana pakan ternak mereka. Namun blotong bisa menjadi salah satu permasalahan mereka karena blotong hanya bisa ditemukan pada saat proses panen tebu saja (Wirosoedarmo, dkk., 2019). Selain itu juga dapat digunakan sebagai alternatif dalam penyelesaian permasalahan kekurangan makan dalam proses ternak cacing. Tingginya potensi pasar lokal, nasional ekspor dan kelebihan teknologi budidaya menjadi faktor sebuah produk perlu dikembangkan (Kudsiah, dkk., 2018a). Produk dari cacing juga mempunyai potensi tinggi.

CV. Rumah Alam Jaya (RAJ) Organik sebagai tempat yang memproduksi pakan cacing menggunakan bahan baku sampah organik menjadi mitra dalam program ini. Namun, terdapat kendala dalam produksi yaitu alat cara pembuatan bahan pakan pada cacing yang masih dilakukan secara tradisional dan membutuhkan waktu lama. Oleh karena itu diperlukan penerapan teknologi untuk meningkatkan nilai jual (Kudsiah, dkk., 2018b). Selain itu, teknologi juga dapat meningkatkan produktifitas (Mawardi, dkk., 2020). Solusi yang ditawarkan yaitu membuat Mesin Blender Sampah Organik yang dapat mencacah sampah untuk dimanfaatkan sebagai pakan cacing, menggunakan bahan baku sampah organik untuk metode sarana alternatif pakan cacing.

Program penerapan teknologi pembuatan pakan cacing diharapkan dapat memberi manfaat kepada mitra yaitu kualitas terjadi peningkatan kualitas produk, jumlah produk bertambah banyak, kapasitas produksi meningkat sehingga jumlah omset pun meningkat. Selain itu, melalui program ini juga dapat merubah paradigma masyarakat untuk memanfaatkan sampah sebagai pakan cacing sehingga akan meminimalisir pengeluaran dengan jumlah besar untuk membeli pakan cacing. Manafaat lainnya adalaj dapat menjadi salah satu media alternatif dalam pemberian pakan tanpa harus menggunakan blotong yang hanya bisa dimiliki ketika musim panen tebu tiba.

\section{Metode Pelaksanaan}

Tempat dan Waktu. Tempat kegiatan pengabdian dilaksanakan di Kelurahan Sukun sejak tahun 2018 hingga bulan Mei 2019. Pemilihan lokasi ini dikarenakan rata-rata pengusaha UMKM, banyaknya ditemukan sampah, dan kesadaran partisipasi masyarakat setempat dalam mengolah sampah masih rendah.

Khalayak Sasaran. Khalayak sasaran dari kegiatan pengabdian ini adalah CV. RAJ Organik (Rumah Alam Jaya Organik). CV. RAJ Organik merupakan sentra budidaya cacing terpadu berbasis organik serta memproduksi bermacam produk olahan cacing.

Metode Pengabdian. Metode yang digunakan adalah pengabdian kepada masyarakat, yakni memberikan pendampingan kepada masyarakat yang ada di Kelurahan Sukun dalam memanfaatkan lingkungan untuk UMKM dengan mengolah sampah organik sebagai pakan cacing. Mekanisme dan tahapan kegiatan program penerapan teknologi tepat guna ini dilakukan untuk memperjelas tujuan dan rencana kegiatan PKM yang ditunjukkan pada Gambar 1. Terdapat lima tahapan pelaksanaan yang dilakukan yaitu survey lokasi, diskusi kelompok, studi literatur, pembuatan alat, percobaan alat dan evaluasi hasil.

Indikator Keberhasilan. Indikator keberhasilan kegiatan pengabdian ini adalah dihasilkannya mesin blender untuk pengolahan sampah menjadi pakan cacing di Kecamatan Sukun Kota Malang. Dengan adanya mesin tersebut maka kualitas dan kapasitas produksi meningkat. Seiring meningkatnya kualitas dan kapasitas produksi maka jumlah omzet meningkat.

Metode Evaluasi. Pada tahap ini evaluasi dilaksanakan oleh tim secara berkala yaitu melihat kendala yang di hadapi setelah proses pembuatan alat selesai. Evaluasi dilaksanakan untuk mengetahui tingkat kesuksesan dan keberlanjutan 


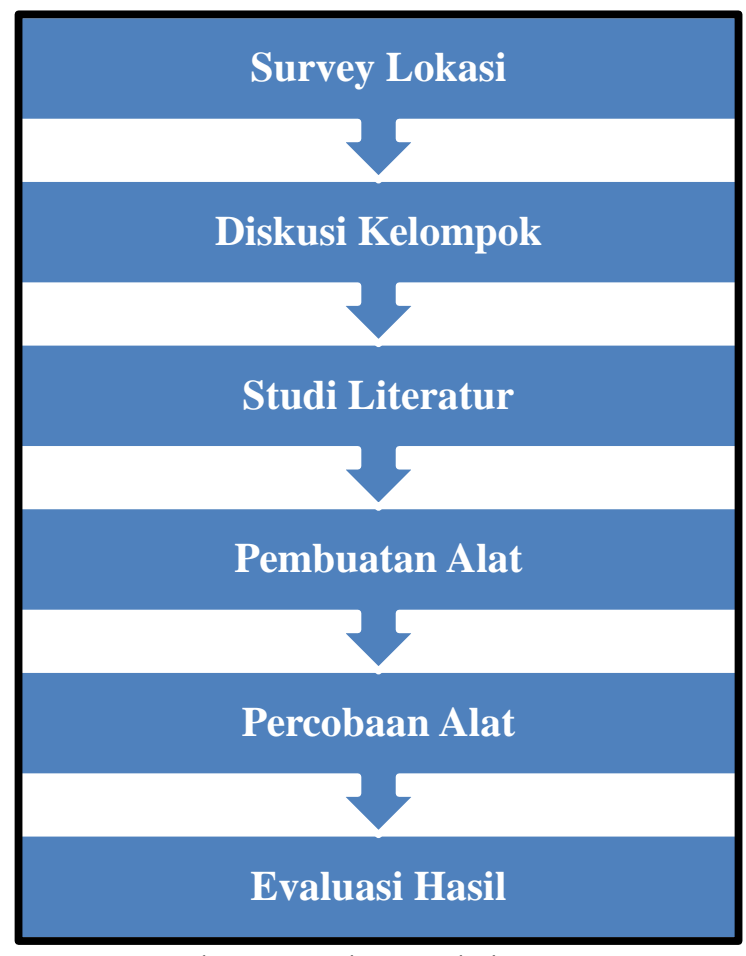

Gambar 1. Alur pelaksanaan

mesin setelah masa kegiatan selesai. Evaluasi akhir nanti akan melalui beberapa Indikator, yaitu antara lain :

a. Mengevaluasi rancangan mesin yang diproduksi.

b. Menguji kinerja mesin yang diproduksi.

c. Melihat tingkat kebutuhan teknologi tepat guna yang akan di terapkan nanti.

d. Ikut serta peran masyarakat dalam kegiatan tersebut.

e. Tingkat kemampuan masyarakat dalam menjalankan alat maupun mesin.

f. Tingkat kemampuan masyarakat dalam proses perawatan, perbaikan atau cara mengatasi permasalahan dalam pengoperasian alat.

g. Meningkatkan produktivitas masyarakat sekitar.

\section{A. Survey Lokasi}

\section{Hasil dan Pembahasan}

Pemilihan lokasi didasarkan pada wilayah yang rata-rata pengusaha UMKM, serta banyaknya sampah di wilayah tersebut dan kesadaran partisipasi masyarakat setempat dalam mengolah sampah masih rendah untuk itu pemilihan lokasi ini ditetapkan sesuai kesepakatan bersama. Maka, dipilih Kelurahan Sukun, Kota Malang. Di lokasi tersebut terdapat banyak sampah yang menumpuk, baik itu sampah kering maupun sampah basah. Dengan hal ini terdapat banyak tong sampah yang disediakan namun tong tersebut di angkut 2 hari sekali. Akibatnya terjadi penumpukan sampah yang terus berkelanjutan, Tim pelaksana dan mitra mempunyai cara untuk mengolah sampah menjadikan pakan cacing.

\section{B. Diskusi Kelompok}

Setelah proses pemilihan lokasi, tahapan ini adalah koordinasi dan komunikasi secara partisipasi dengan tim pelaksana untuk merumuskan program mulai dari perencanaan sampai evaluasi.

\section{Studi Literatur}

Pada tahapan ini adalah permasalahan dan solusi yang diberikan tim pelaksana dalam hasil diskusi untuk masyarakat di Kelurahan Sukun. Studi 
dilakukan untuk mendapatkan rancangan mesin sehingga mendapatkan hasil yang maksimal.

\section{Pembuatan Alat}

Tahap pertama yang dilakukan dalam pembuatan mesin blender sampah organik adalah mendesain mesin dan menentukan spesifikasi dan kapasitas yang dibutuhkan agar menghasilkan mesin yang maksimal. Proses pembuatan mesin diawali dengan pembuatan rangka seperti pada Gambar 2. Mesin yang bahannya didominasi almunium ini didalamnya terdapat mesin pencacah layaknya pisau blender.

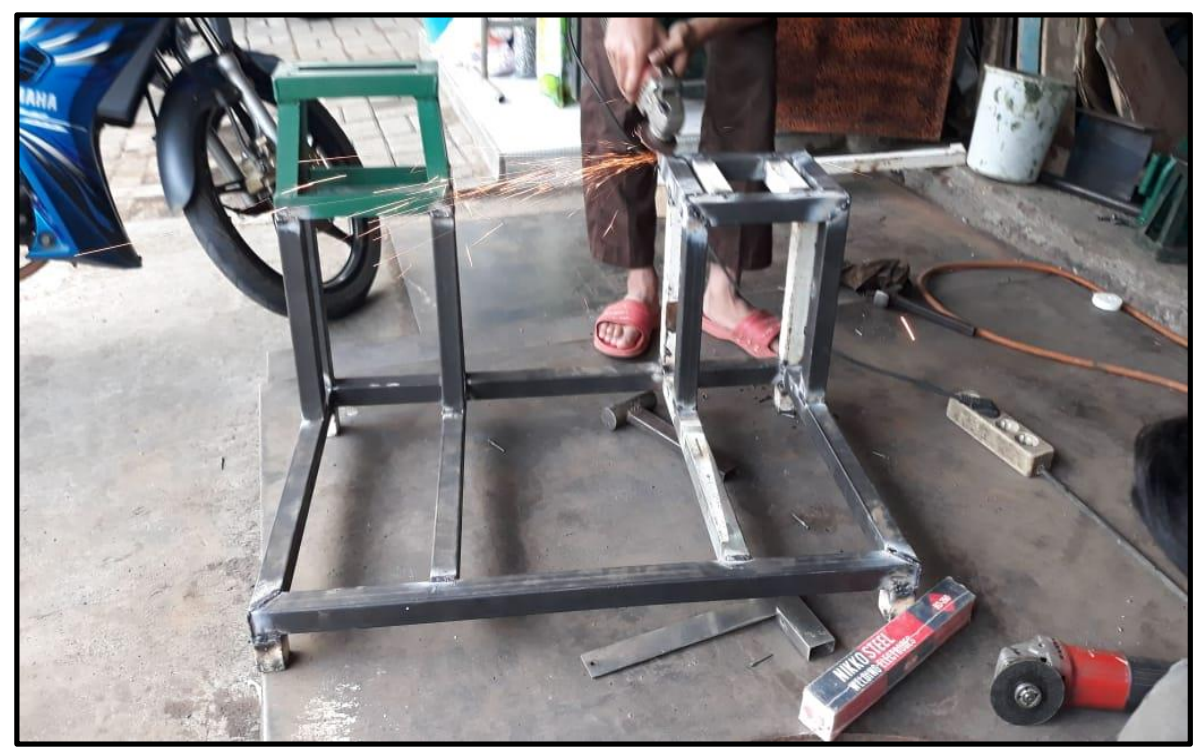

Gambar 2. Proses pembuatan alat

\section{E. Percobaan Alat}

Proses pengolahan sampah organik ini diawali menghidupkan penggerak mesin pengolah sampah. Tahap selanjutnya memasukkan sampah tersebut kedalam mesin chopper atau input mesin pengolah sampah secara bertahap. Kemudian sampah akan di cacah secara bertahap, hasil dari sampah akan menjadi ukuran kecil yang hasilnya akan keluar dari saluran keluar sampah organik. Dalam proses tersebut mampu mencacah daun, ranting, rumput, dan semua jenis sampah yang kering yang bisa digunakan untuk pakan cacing.

\section{F. Evaluasi Hasil}

Pada Gambar 2, merupakan alur proses inovasi pertama yang di mulai dari pemilahan sampah organik dan anorganik. Dengan beberapa jenis sayuran, buah, dan terutama sampah rumah tangga. Sampah tersebut kemudian dimasukkan ke dalam mesin chopper untuk diolah. Mesin chopper ini digunakan untuk mencacah aneka tanaman seperti batang jagung, sayuran dan sampah yang bersifat lunak untuk makanan ternak. Dalam pengolahannya, sampah tersebut yang awalnya buah maupun sayuran akan dipilah dan dicampur menjadi satu. Kemudian sampah tersebut dimasukkan ke dalam mesin chopper untuk dicacah sebagai pakan ternak seperti ditujukan pada Gambar 3.

Setelah proses pencacahan selesai, pakan tersebut bisa digunakan untuk makan cacing. Untuk memberi makan cacing, pakan tersebut akan di masukkan ke tanah yang ada cacingnya pada Gambar 4. Kemudian diberi sedikit air guna untuk mengatasi serangga yang masuk ke dalam olahan pakan tersebut ditujukan pada Gambar 5. Dengan inovasi pertama ini menguji $1 \mathrm{~kg}$ cacing dengan pakan berbahan sampah organik yang memiliki bobot $25 \mathrm{~kg}$. Hasil dari pengujian tersebut 


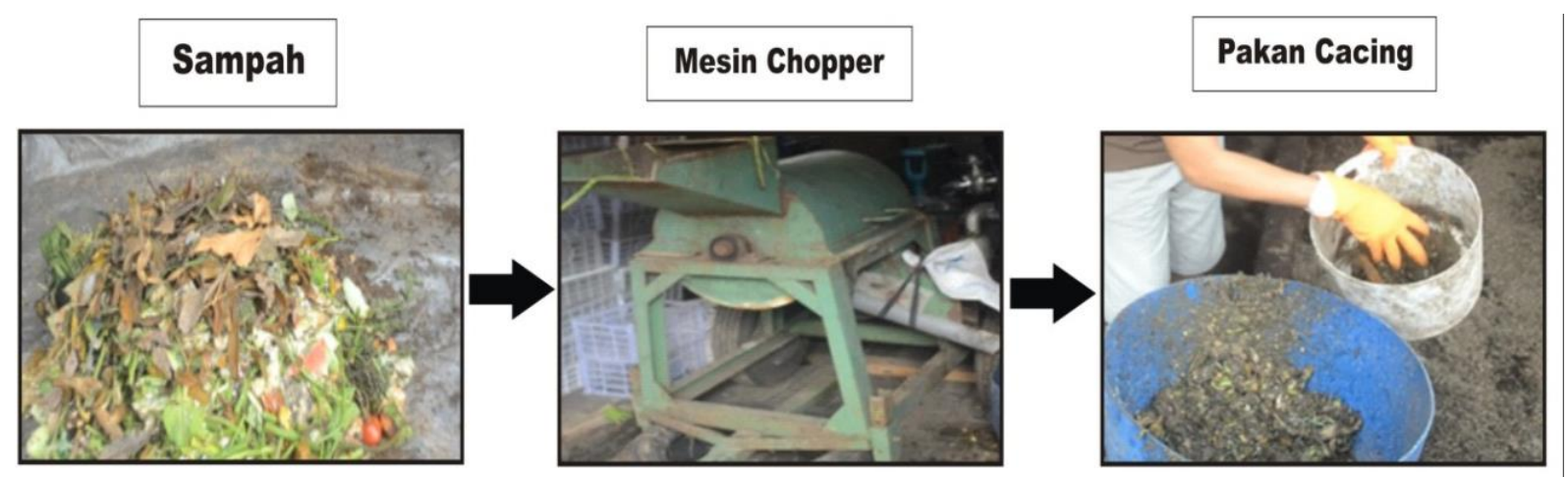

Gambar 3. Proses Pembuatan pakan cacing pada inovasi pertama

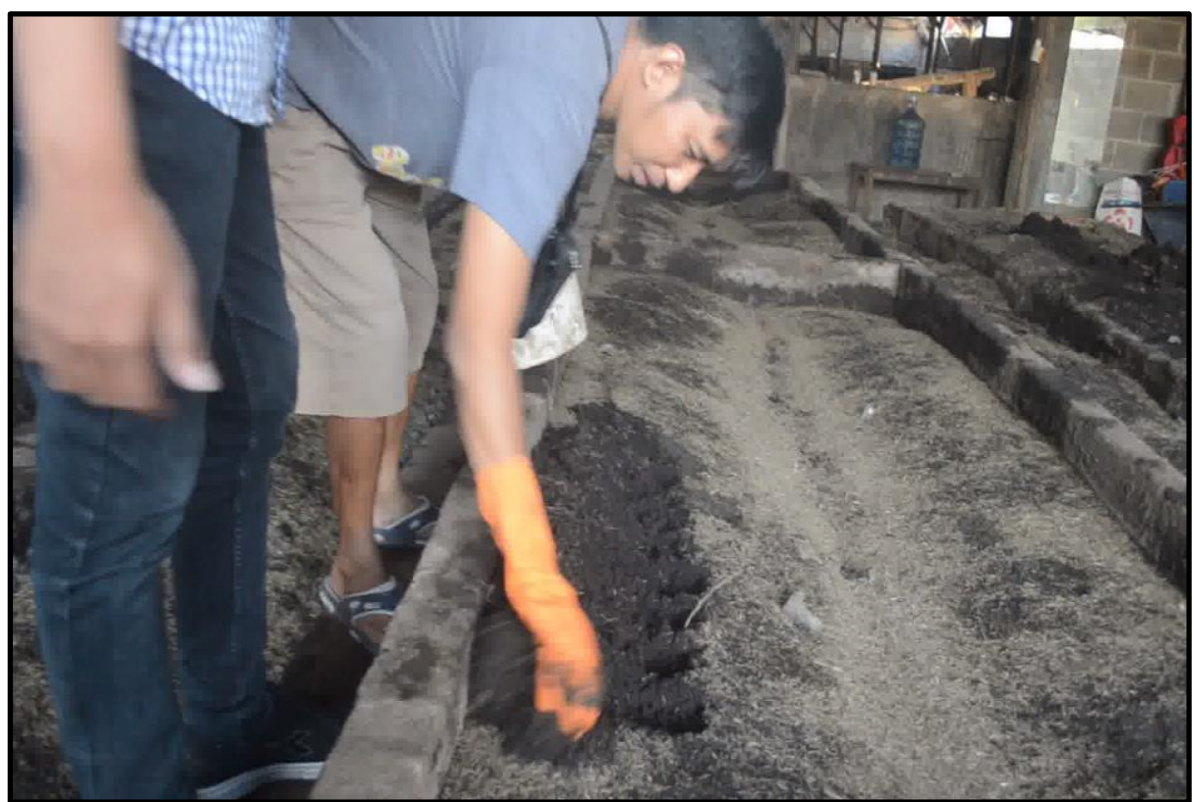

Gambar 4. Proses menggali tanah

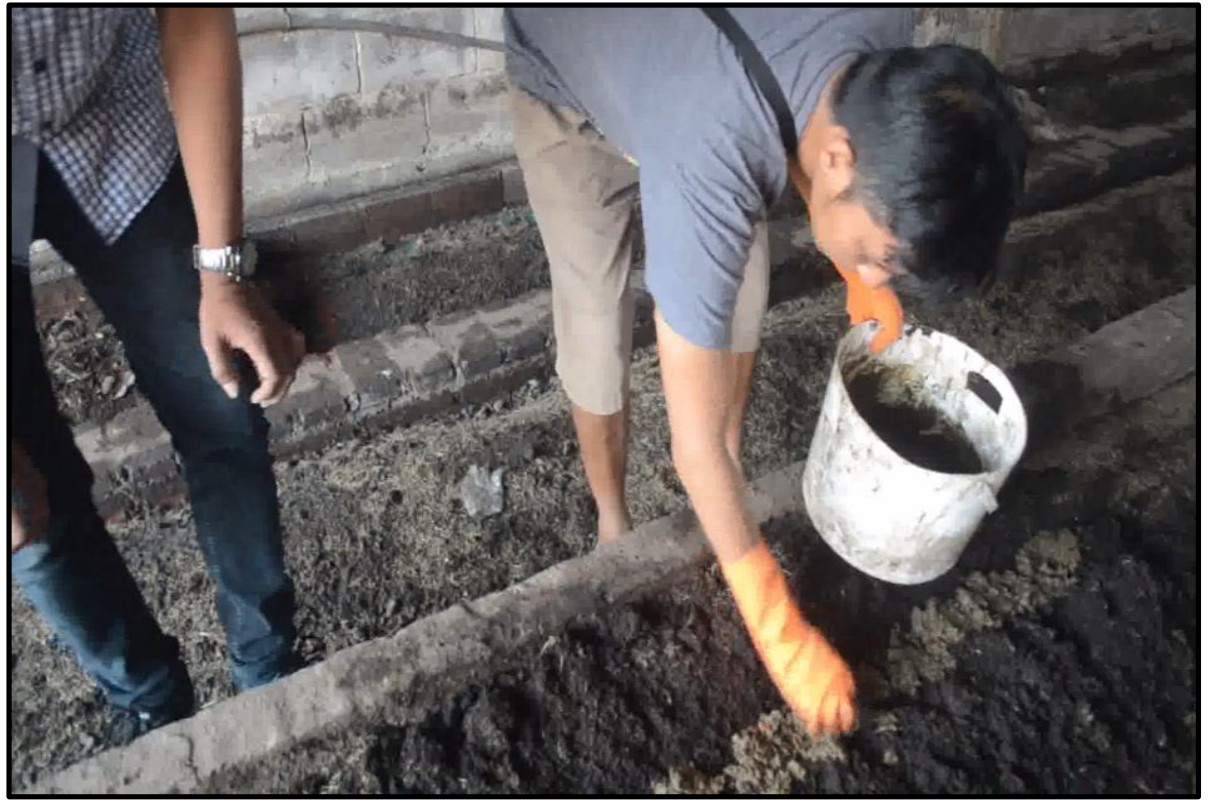

Gambar 5. Proses pemberian makan cacing

Jurnal Panrita Abdi, 2020, Volume 4, Issue 2. 
menunjukkan bahwa sampah yang hanya dicacah namun masih kasar dapat habis dimakan oleh cacing dalam waktu 7 hari. Tahap selanjutnya menggunakan inovasi yang berbeda karena pada inovasi sebelumnya cacing menghabiskan makanannya terlalu lama sampai 7 hari. Untuk itu dengan inovasi kedua ini akan mempersingkat waktu proses makan cacing dalam memakan makanannya.

Pada tahap awal sesuai dengan rencana untuk memilah sampah kering dan sampah basah. Tahap selanjutnya sampah dikumpulkan untuk diolah di mesin chopper. Setelah proses pengolahan di mesin chopper selesai, pakan yang dihasilkan oleh mesin chopper tadi dikumpulkan dalam satu wadah untuk difermentasikan sehingga sampah yang sudah diproses akan menjadi sedikit awet dan tahan lama dalam proses penyimpanannya. Alur dari proses yang menggunakan inovasi kedua ditunjukkan pada Gambar 6.

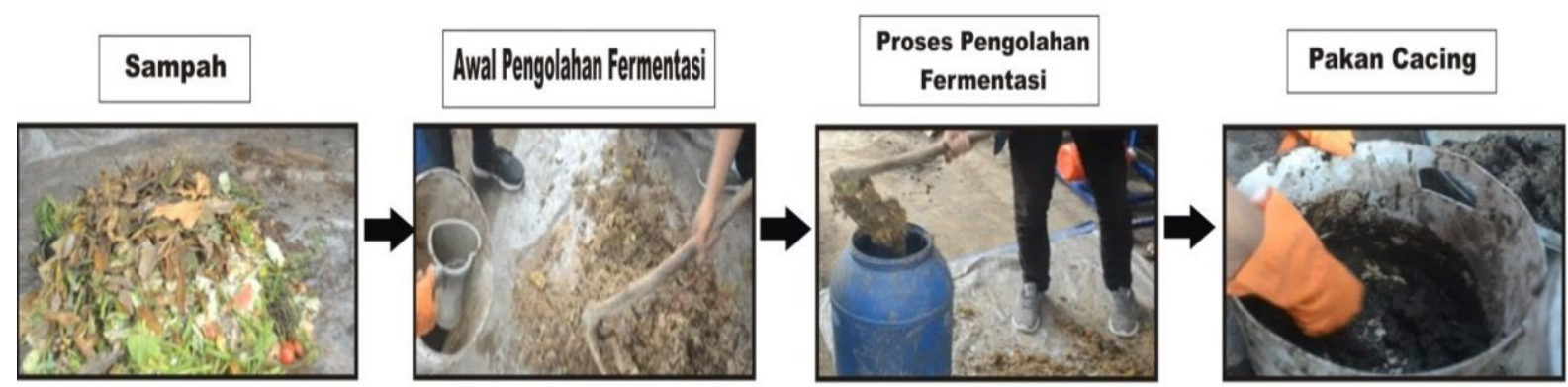

Gambar 6. Proses pembuatan pakan cacing pada inovasi kedua

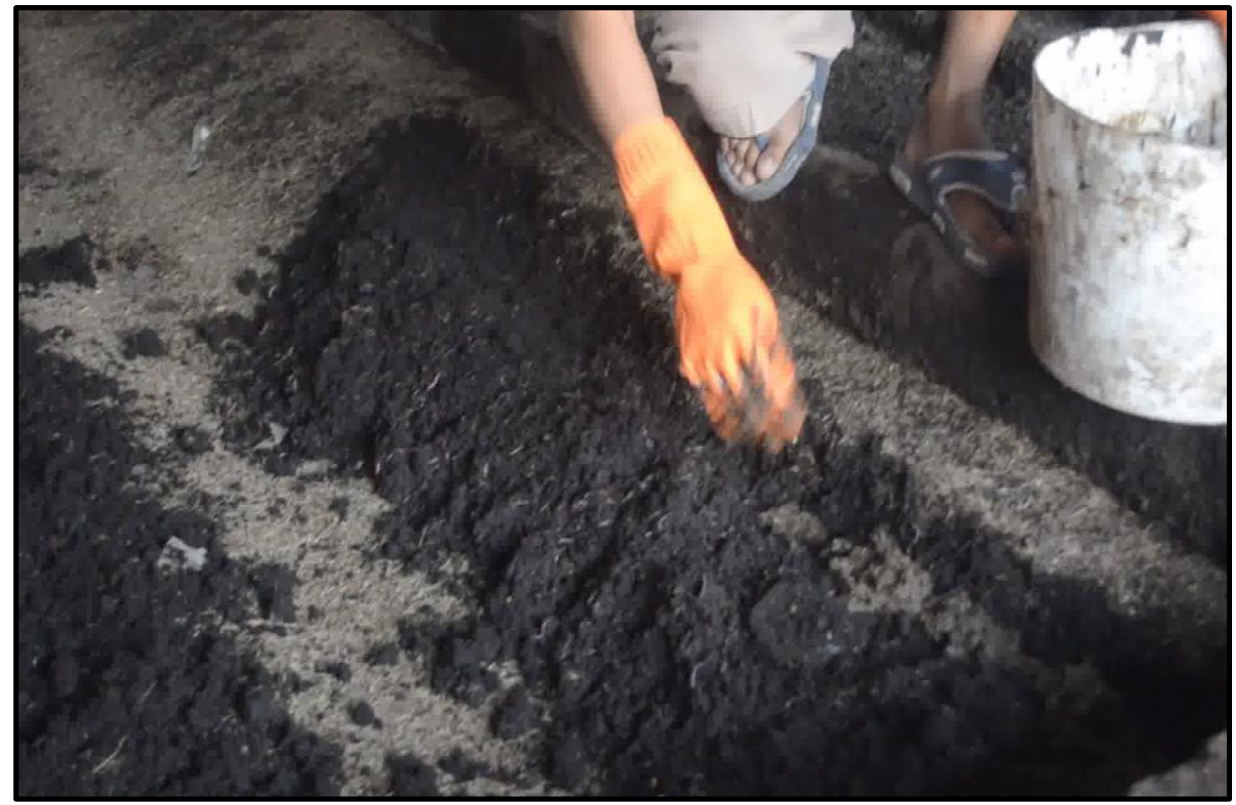

Gambar 7. Proses pemberian makan cacing

Setelah proses fermentasi selesai, tahap selanjutnya proses pemasukan pakan ke dalam cacing sama dengan inovasi pertama. Pakan cacing tersebut dimasukkan ke dalam tanah, kemudian diberi sedikit air agar tidak ada serangga yang masuk ke dalam pakan cacing tersebut ditujukan pada Gambar 7. Dengan inovasi kedua ini ingin menunukkan $1 \mathrm{~kg}$ cacing dengan pakan berbahan sampah organik yang memiliki bobot $25 \mathrm{~kg}$. Hasil dari kegiatan ini menunjukkan bahwa sampah yang hanya dicacah namun sedikit kasar dan tidak bau dapat di habis dimakan oleh cacing dalam waktu 3 hari. Dalam kegiatan inovasi selanjutnya membuat olahan pakan cacing tersebut agar lebih singkat. Karena pada proses inovasi yang pertama dan kedua cacing mengalami kendala dalam proses mencerna makanan sehingga 
proses waktu dalam menghabiskan makanannya terlalu lama. Pada Gambar 8 merupakan alur proses mulai dari pemilahan sampah hingga proses pemberian pakan pada cacing. Proses ini diawali dengan pemilahan sampah, baik itu sampah kering maupun basah. Pada proses pemilahan, sampah yang diperlukan adalah sampah yang lunak. Sampah yang lunak berupa sayur-sayuran, maupun buahbuahan, sampah tersebut harus dipilih karena cepat mengalami pembusukan.

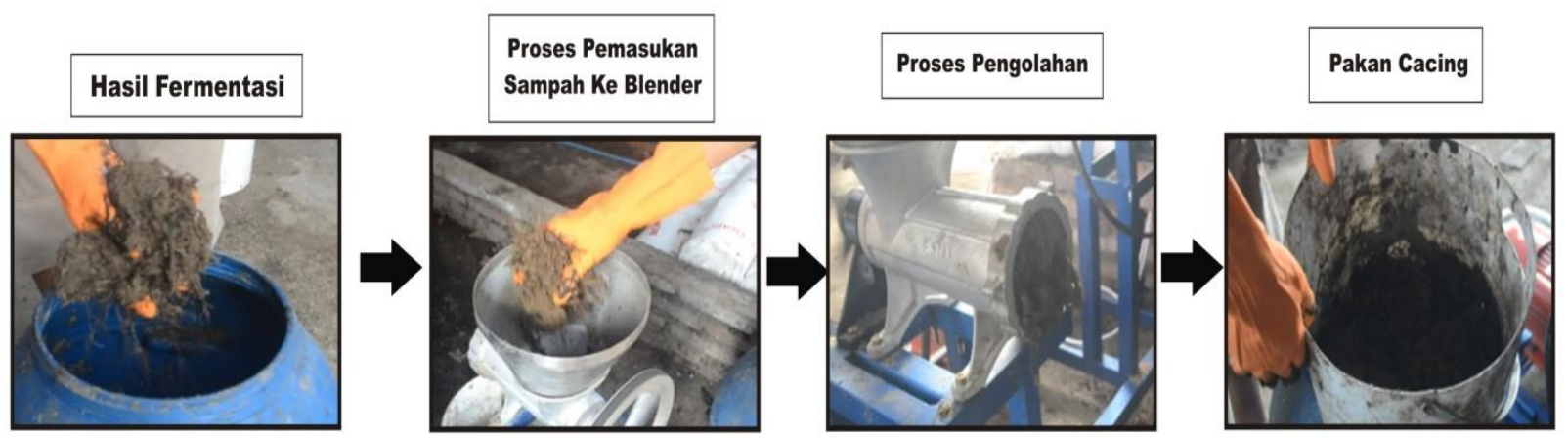

Gambar 8. Proses Pembuatan Pakan Cacing Pada Inovasi Ketiga

Tahap selanjutnya memasukkan sampah yang sudah dipilah kedalam mesin chopper. Setelah proses pengolahan di mesin chopper selesai, kemudian hasil dari sampah tersebut dimasukkan ke sebuah wadah untuk difermentasi. Hasil fermentasi pengolahan sampah kemudian dimasukkan ke dalam mesin blender. Proses ini untuk menghaluskan hasil dari pengolahan tersebut yang sebelumnya masih berupa cacahan yang sedikit kasar. Setelah proses blender selesai, pakan tersebut sudah bisa digunakan untuk makan cacing.

Proses pemberian makan pada cacing sama dengan inovasi pertama dan kedua. Yaitu di masukkan ke dalam tanah, kemudian diberi sedikit air agar tidak ada serangga yang masuk ke dalam pakan cacing tersebut ditujukan pada Gambar 9. Dengan inovasi ketiga ini ingin ditunjukkan $1 \mathrm{~kg}$ cacing dengan pakan berbahan sampah organik yang memiliki bobot $25 \mathrm{~kg}$. Hasil dari kegiatan menunjukkan bahwa sampah yang hanya dicacah namun sedikit kasar dan tidak bau dapat di habis dimakan oleh cacing dalam waktu 2 hari.

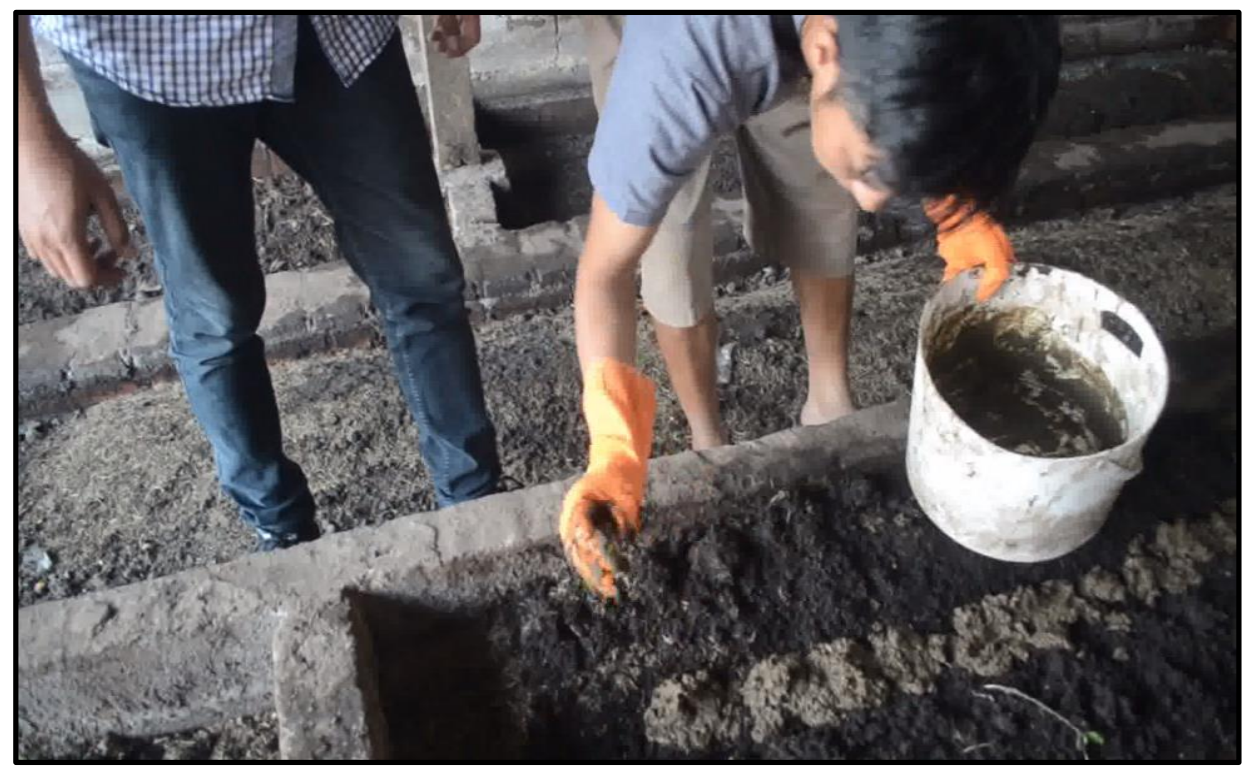

Gambar 9. Proses Pemberian Makan Cacing 


\section{G. Keberhasilan Kegiatan}

Berdasarkan hasil evaluasi dan indikator keberhasilan, kegiatan pengabdian kepada masyarakat ini telah berjalan dengan baik. Dengan menggunakan mesin blender sampah organik, membuat proses produksi sangat efisien dan singkat dibandingkan dengan proses sebelumnya. Sebelum kegiatan ini berlangsung, cacing membutuhkan waktu yang lama menghabiskan makanannya karena partikel sampah masih berukuran besar. Namun setelah menggunakan mesin blender sampah organik ini, cacing mampu menghabiskan makanannya hanya dalam waktu 2 hari. Karena proses lebih singkat, maka terjadi peningkatan kualitas dan kapasitas produksi yang berdampak pula dengan peningkatan omset. Selain itu, karena proses makan cacing tidak terlalu lama maka proses penumpukan sampah semakin minimal.

\section{Kesimpulan}

Pada kegiatan ini telah berhasil membuat mesin blender pengolah sampah yang dapat membuat proses pengolahan sampah sebagai pakan cacing menjadi efektif. Dengan menggunakan mesin blender sampah organik ini cacing mampu menghabiskan makanan lebih cepat yaitu 2 hari, sedangkan sebelumnya membutuhkan waktu 7 hari. Hal tersebut menyebabkan terjadinya peningkatan kualitas dan kapasitas produksi. Proses produksi menjadi efisien karena proses makan cacing tidak terlalu lama dan proses penumpukan sampah semakin minimal.

\section{Ucapan Terima Kasih}

Penulis mengucapkan terimakasih kepada Direktorat Riset dan Pengabdian Masyarakat (DRPM) atas hibah yang diberikan pada Program Kemitraan Masyarakat (PKM) yang dilaksanakan pada tahun 2019, Selanjutnya ucapan terima kasih kepada Mitra Pengabdian yaitu CV. RAJ Organik (Rumah Alam Jaya Organik) atas kerjasama dalam proses pengabdian masyarakat. Semoga kerja sama ini berlanjut pada tahun berikutnya.

\section{Referensi}

Alfan, M. (2017). Dampak Tempat Pembuangan Akhir (TPA) Sampah Kongok terhadap Gangguan Kesehatan Masyarakat Desa Suka Makmur Kecamatan Gerung Kabupaten Lombok Barat Tahun 2017 (Disertasi Doktor, Universitas Islam Negeri Mataram).

Alfiandri, Legowo, E.H., Audah, K.A., \& Adam, M.R.R. (2018). Waste Disposal Facilitation For Desa Keranggan Society-Swiss German University Community Service Project. Jurnal Sinergitas PKM \& CSR, 3(1), 25-34.

Angelo, C., Setiawan, A.P., \& Poilot, J.F. (2019). Penelitian Ampas Tebu sebagai Material Pembuatan Papan Unting. Jurnal Intra, 7(2), 511-514.

Antin, T., Wahyuni, H.I., \& Partini. (2018). Dinamika Peran Jejaring Pengelolaan Sampah dalam Komunikasi Literasi Sampah. Profetik Jurnal Komunikasi, 11(2), 116-130. https://doi.org/10.14421/pjk.v11i2.1479

Aprilia, N. (2016). Evaluasi Pengelolaan Sarana Pendukung yang Ramah Lingkungah pada Program Adiwiyata di SMP Muhammadiyah di Kota Yogyakarta. Seminar Nasional XI Pendidikan Biologi FKIP UNS, XI(1), 769-775.

Arnawa, I.K., \& Pandawani, N.P. (2019). Pemberdayaan Masyarakat Desa Baha Kecamatan Mengwi Kabupaten Badung dalam Bidang Pengeloaan Sampah. Jurnal Abdi Saraswati, 1(1), 12-17.

Astuti, A.D. (2019). Analisis Potensi Dampak Lingkungan dari Budidaya Tebu Menggunakan Pendekatan Life Cycle Assessment (LCA). Jurnal Litbang, XV(1), 51-64. 
Humaedi, S., Adharani, Y., \& Herliani, Y.K. (2018). Peningkatan Kapasitas Masyarakat dalam Pengelolaan Sampah Secara Mandiri dan Pemetaan Sosial. Jurnal Penelitian \& PPM, 5(1), 56-60.

Kudsiah, H., Tresnati, J., Ali, S. A., \& Rifa'i, M. A. (2018a). IbM Kelompok Usaha Bandeng Segar Tanpa Duri di Kabupaten Pangkep Sulawesi Selatan. Jurnal Panrita Abdi, 2(1), 55-63.

Kudsiah, H., Rahim, S.W., Rifa'i, M.A., \& Arwan. (2018b). Demplot Pengembangan Budidaya Kepiting Cangkang Lunak di Desa Salemba, Kecamatan Ujung Loi, Kabupaten Bulukumba Sulawesi Selatan. Jurnal Panrita Abdi, 2(2), 151-164.

Lando, A.T., Arifin, A.N., Selintung, M., Sari, K., Djamaluddin, I., \& Caronge, M.A. (2019). Sosialisasi dan Pendampingan Sistem Pengelolaan Sampah Menjadi Kompos Skala Sekolah di SD Inpres Kantisang, Tamalanrea. Jurnal Panrita Abdi, 3(2), 113-124.

Mahyudin, R.P. (2017). Kajian Permasalahan Pengelolaan Sampah dan Dampak Lingkungan di TPA (Tempat Pemrosesan Akhir). Jukung (Jurnal Teknik Lingkungan), 3(1), 66-74.

Martana, B., Nashir, A.K., Pradana, S., \& Sugianto. (2018). Pengolahan Sampah Plastik Menjadi Produk Lainnya Sebagai Upaya Peningkatan Ekonomi Masyarakat. Prosiding Seminar Hasil Pengabdian (SNP2M) 2018, 23-25.

Masrida, R. (2017). Kajian Timbulan dan Komposisi Sampah Sebagai Dasar Pengelolaan Sampah di Kampus II Universitas Bhayangkara Jakarta Raya. Journal of Env. Engineering \& Waste Management, 2(2), 69-78.

Mawardi, I., Nurdin, \& Zulkarnain. (2020). Inovasi Mesin-Mesin Teknologi Pascapanen Kopi sebagai Produk Usaha Intelektual Kampus Politeknik Negeri Lhokseumawe. Jurnal Panrita Abdi, 4(1), 24-33.

Meilani, S.S., \& Kartika, W. (2019). Reduksi Sampah Anorganik dengan Pemberdayaan Ekonomi Masyarakat Melalui Kegiatan Bank Sampah di RW 17 Kecamatan Rawa Lumbu Kelurahan Bojong Rawa Lumbu Kota Bekasi. Jurnal Abdimas UBJ, 2(1), 1-7.

Munawir, Masnida, \& Mahbub. (2019). Pemberdayaan Remaja dalam Upaya Menumbuhkan Kesadaran Masyarakat dalam Pengelolaan Sampah. Jurnal Loyalitas, II(1), 101-111.

Pratiwi, E.Z., Meidiana, C., \& Wijayanti, W.P. (2018). Rekomendasi Penentuan Titik Tempat Penampungan Sampah Sementara di Kecamatan Kedungkandang Kota Malang. Jurnal Tata Kota Dan Daerah, 10(1), 25-38.

Rahman, A. Y., Setiawan, F. W., \& Hananto, A.L. (2020). Pemberdayaan Kepada Kelompok Pengolah Sampah Organik Sebagai Pakan Cacing Di Kecamatan Sukun Kota Malang. Jurnal Abdimas Mahakam, 4(1), 46-55. https://doi.org/http://dx.doi.org/10.24903/jam.v4i1.753

Rukminasari, N., Indar, Y.N., Sitepu, F., Parawansa, B.S., Suharto, Irmawati, \& Inaku. D.F. (2016). Pengelolaan Lingkungan Pantai Melalui Pengembangan Bank Sampah Sebagai Upaya Bersih Pantai dan Pemberian Nilai Tambah Sampah Daur Ulang di Pantai Losari, Kota Makassar. Jurnal Panrita Abdi, $1(1), 67-75$.

Salendu, F.N., \& Hadi, Y. (2018). Analisis dan Pemodelan Sistem Pengeloaan Sampah Yang Ada Di Universitas Ma Chung. KURAWAL: Jurnal Teknologi, Informasi, Dan Industri, 1(2), 82-88.

Sudiro, Setyawan, A., \& Nulhakim, L. (2018). Model Pengelolaan Sampah Permukiman Di Kelurahan Tunjung Sekar Kota Malang. Jurnal Plano Madani, 7(1), 106-117. https://doi.org/10.24252/planomadani.v7i1a10

Suryani, A. S. (2014). Peran Bank Sampah Dalam Efektivitas Pengelolaan Sampah (Studi Kasus Bank Sampah Malang). Jurnal Aspirasi, 5(1), 71-84.

Susmarkanto. (2002). Pencemaran Lingkungan Perairan Sungai Salah Satu Faktor Penyebab Banjir Di Jakarta. Jurnal Teknologi Lingkungan, 3(1), 13-16. 
https://doi.org/10.29122/JTL.V3I1.230

Wirosoedarmo, R., Santoso, S.E., \& Anugroho, F. (2019). Pengaruh Pemberian Media Berbahan Limbah Kotoran Sapi dan Blotong Tebu terhadap Bobot dan Kadar Protein Cacing African Night Crawler (Eudrilus Eugenia). Jurnal Sumberdaya Alam Dan Lingkungan, 6(1), 33-40.

Penulis:

Aviv Yuniar Rahman, Program Studi Teknik Informatika, Fakultas Teknik, Universitas Widyagama Malang. E-mail: aviv@widyagama.ac.id

Feddy Wanditya Setiawan, Program Studi Teknik Otomotif, Politeknik Hasnur Barito Kuala. E-mail: feddy@polihasnur.ac.id

April Lia Hananto, Program Studi Sistem Informasi, Fakultas Teknik dan Ilmu Komputer, Universitas Buana Perjuangan Karawang. E-mail: aprilia@upbkarawang.ac.id

Bagaimana men-sitasi artikel ini:

Rahman, A.Y., Setiawan, F.W., \& Hananto, A.L. (2020). Aplikasi Teknologi Tepat Guna untuk UMKM Pengolahan Sampah Organik sebagai Pakan Cacing. Jurnal Panrita Abdi, 4(2), 205-215. 